\title{
Taxonomic position of the two sympatric forms of Chondracanthus chamissoi (f. lessonii and f. chauvinii) (Rhodophyta, Gigartinaceae) by using two molecular markers
}

\author{
Catalina Y. Rodríguez ${ }^{1,2}$, Florence Tellier ${ }^{1,2}$, Karla Pérez-Araneda ${ }^{1,2} \&$ Ricardo D. Otaíza $^{1,2}$ \\ ${ }^{1}$ Departamento de Ecología, Facultad de Ciencias, Universidad Católica de la Santísima Concepción \\ Concepción, Chile \\ ${ }^{2}$ Centro de Investigación en Biodiversidad y Ambientes Sustentables (CIBAS) \\ Universidad Católica de la Santísima Concepción, Concepción, Chile \\ Corresponding author: Florence Tellier (ftellier@gmail.com)
}

\begin{abstract}
The red seaweed Chondracanthus chamissoi shows high morphological variability. Initially, three species were identified based on the width of the main axis of their blades. Later, all of them were included in a single species with two morphological groups. Recently, quantitative studies demonstrated the existence of two forms in C. chamissoi: f. lessonii and f. chauvinii. It was also shown that these two forms occur in sympatry, growing side by side. These forms were not associated with either a life cycle phase or the sex of the blades. This study aimed to determine whether the two forms could represent different species. We evaluated the forms' taxonomic position using COI and $r b c \mathrm{~L}$ markers, including samples from three localities in southern Chile. All specimens shared a single $r b c \mathrm{~L}$ haplotype, whereas the two COI haplotypes differed by four base pairs and were present in blades of both forms and life cycle phases. The two morphological types correspond to intraspecific forms. This species is of commercial importance, and its main market is aimed at human consumption with a marked preference for f. lessonii.
\end{abstract}

Keywords: Chondracanthus chamissoi; seaweed; COI; rbcL; forms; sympatric; morphological variability; coexistence

Chondracanthus chamissoi (Rhodophyta, Gigartinaceae) is a red seaweed that extends geographically from Paita, Peru $\left(5^{\circ} \mathrm{S}\right)$, to Ancud, Chile $\left(42^{\circ} \mathrm{S}\right)$ (Ramírez \& Santelices 1991). Recent genetic analyses indicated that this species is also present in Korea and Japan, where it has been confused with $C$. teedei (Yang et al. 2015). In Chile, this species has been harvested and exported for the carrageenan industry (Hoffmann \& Santelices 1997) and human consumption, mainly to Asian countries (Bulboa \& Macchiavello 2006). Like many red seaweeds, C. chamissoi has a Polysiphonia-type, triphasic life cycle, alternating isomorphic gametophytic and sporophytic generations (Hoffmann \& Santelices 1997, Avila et al. 2011).

C. chamissoi shows great morphological variability of blades throughout its geographical distribution range (Howe 1914, Dawson et al. 1964, Santelices 1989,
Ramírez \& Santelices 1991, Bulboa \& Macchiavello 2006, Rodríguez \& Otaíza 2018).

Howe (1914) recognized three species based on the width of the blades' main axis in samples from Peru. He named Gigartina chamissoi those with intermediate blade width, G. lessonni those with more extreme narrow blades, and G. chauvinii those with broad main axes. Nevertheless, Howe (1914) admitted that the distinction of these species' morphological limits was difficult to establish. Later, Dawson et al. (1964) included G. lessonii and G. chauvinii as two morphological groups within G. chamissoi, the "lessonii group" with the main axis of 3-5 $\mathrm{mm}$ in width and the "chauvinii group" with the main axis of $20 \mathrm{~mm}$ or more. Ramírez \& Santelices (1991) retained the distinction into three species until new studies provide more information. Ecological and culture studies have been

Corresponding editor: Loretto Contreras 
done in Chile regarding the high morphological variability of $C$. chamissoi (e.g. González \& Meneses 1996, Vásquez \& Vega 2001, Bulboa \& Macchiavello 2006, Fonck et al. 2008, Sáez et al. 2008, Otaíza \& Fonseca 2011, Bulboa et al. 2013, Rodríguez \& Otaíza 2018, Arbaiza et al. 2019, Zapatas-Rojas et al. 2020, Oyarzo et al. 2021) but did not distinguish between morphological groups.

In previous studies, morphological variability was solely distinguished based on the width of the main axis. Still, recently Rodríguez \& Otaíza (2020) quantitatively characterized more than 1000 thalli, including sporophytic and male and female gametophytic blades collected from three localities in the Biobío Region (southern Chile) and, for one of the localities, blades were collected in two seasons of the year. Their results clearly showed two distinct forms: gametophytes and sporophytes in the three localities and the two seasons. The two forms are discrete entities, differing statistically in four morphological characters. Apart from the narrow central axes, f. lessonii was characterized by having thick and curved (i.e., channeled) central axes and few or no spines on the surface (Fig. 1). On the other hand, f. chauvinii had wide and thinner central axes, flat, and numerous spines on both surfaces (Rodríguez \& Otaíza 2020). Furthermore, their results show that thalli conform two separate groups in multivariate analyses, and there were no individuals with a different combination of characters.

An explanation based on differences among phases of the life cycle (e.g. heteromorphy or sexual dimorphism), as is the case with other species (e.g. Drew 1949, Van der Meer \& Todd 1980), is not supported by the results obtained by Rodríguez \& Otaíza (2020), who found both forms across gametophytes and sporophytes. Additionally, these authors showed that the forms occurred in sympatry, collected side by side, in the same patches. Sympatric occurrence of two distinct morphological forms is a rare phenomenon. Considering that morphological variability, generally described for red seaweeds like ecotypes or ecomorphs, is the result of growth in different environments, geographically separated (e.g. Gutierrez \& Fernández 1992, Brodie et al. 1993, Shaughnessy 1996, Edding et al. 2006, Faria et al. 2017). Howe (1914) suggested one possible explanation: that the two forms correspond to two different species, reproductively isolated.

This study aimed to evaluate the taxonomic position of the two forms documented by Rodríguez \& Otaíza (2020) for $C$. chamissoi, to determine whether consistent genetic differences occur by using a genetic characterization using two DNA molecular markers. In

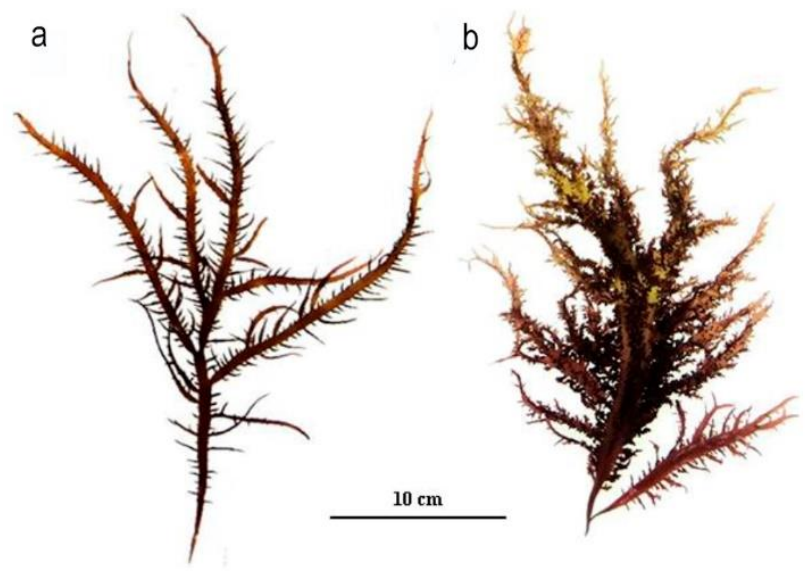

Figure 1. Two forms of Chondracanthus chamissoi described by Rodríguez \& Otaíza (2020), a) tetrasporophitic blade of f. lessonii, b) female blade of f. chauvinii. Both specimens were collected from the same patch in summer 2018 in Cocholgüe, Chile.

red seaweeds, the mitochondrial gene cytochrome $\mathrm{C}$ oxidase subunit I (COI), and the plastidial $r b c \mathrm{~L}$ gene, corresponds to the large subunit of ribulose-1,5biphosphate carboxylase/oxygenase (RuBisCo). They have been used together for the identification of taxa at a generic and species level, and even at the intraspecific level (e.g. Gurgel \& Fredericq 2004, Kim et al., 2006, Yang et al. 2013, López et al. 2017), including studies on species of the genus Chondracanthus (Schneider \& Lane 2005, Hughey \& Hommersand 2008), and in $C$. chamissoi itself (Yang et al. 2015). The latter study was done using both markers, including samples from Chile, without considering the forms (Yang et al. 2015).

Female gametophytic blades, identified by the presence of cystocarps, were collected randomly from shallow platforms (1-2 $\mathrm{m}$ of depth) at three localities in the Biobío Region, southern Chile: Ramuntcho $\left(36^{\circ} 45^{\prime} 06^{\prime \prime S}, 73^{\circ} 11^{\prime} 04^{\prime \prime} \mathrm{W}\right)$, Cocholgüe $\left(36^{\circ} 35^{\prime} 15^{\prime \prime} \mathrm{S}\right.$, $\left.72^{\circ} 58^{\prime} 60^{\prime \prime} \mathrm{W}\right)$ and Punta Lavapié (37 $08^{\prime} 55^{\prime \prime} \mathrm{S}$, 73 $35^{\prime} 13^{\prime \prime W}$ ), between October and November 2017. From each clump, a single blade was collected.

Thalli were classified into f. lessonii and $\mathrm{f}$. chauvinii, according to their morphological characters, as described by Rodríguez \& Otaíza (2020). A small fragment without visible reproductive structures was cut from the fresh thalli and preserved in silica gel until the molecular analysis was done from each individual. Fifty-four individuals were analyzed with the mitochondrial partial gene COI, considering 8-11 thalli of each form and locality. Additionally, a subsample of 12 thalli of each form and locality was analyzed using the $r b c \mathrm{~L}$ plastidial gene. The DNA extraction was done using a GeneJET Genomic DNA Purification (Thermo Scientific $\left.{ }^{\mathrm{TM}}\right)$, following the manufacturer's protocol, 
and the resulting DNA was stored at $-20^{\circ} \mathrm{C}$ until it was processed. Amplification of the COI gene was done using the primers designed by Saunders (2005) for red seaweeds (GazF1: 5' TCAACAAATCATAAAGAT ATTGG 3' and GazR2: 5' ACTTCTGGATGTCCA AAAAAYCA 3') following the PCR conditions described by Fraser et al. (2009). For the amplification of the $r b c \mathrm{~L}$ gene, the specific primers F7 and R753 (F7: 5' AACTCTGTAGAACGNACAAG 3'; R753: 5' GCT CTTTCATACATATCTTCC 3') (Gavio \& Fredericq 2002) were used, with the conditions of the PCR described by Boo et al. (2013). Amplifications of both molecular markers were done using DNA GoTaq polymerase Fermelo Biotec (Promega, Madison, USA), in a Verity (Applied Biosystems, Foster City, USA). PCR products were purified and sequenced by Macrogen Inc. (Seoul, South Korea) using GazR2 primer for $\mathrm{COI}$ and $\mathrm{F} 7$ for $r b c \mathrm{~L}$. The edition, alignment of multiple sequences, and identification of polymerphic sites were made with BioEdit 7.2.5 (Hall 1999). The obtained sequences were analyzed using BLAST in GenBank (https://blast.ncbi.nlm.nih.gov/Blast.cgi; Altschul et al. 1990) to identify coincidences with other sequences in GenBank, including those published by Yang et al. (2015) for C. chamissoi.

Considering 698 base pairs (bp), the nine sequences obtained for $r b c \mathrm{~L}$ corresponded to a single haplotype identical to the sequences of $C$. chamisso $i$ available in GenBank (GenBank access number KP059091.1). The 54 sequences obtained from COI resulted in an alignment of $672 \mathrm{bp}$, with two haplotypes, named $\mathrm{H} 1$ and $\mathrm{H} 2$. Both haplotypes coincided (100\% similarity) with GenBank sequences of $C$. chamissoi collected in Chile. $\mathrm{H} 1$ has been reported from Tarapacá $\left(18^{\circ} \mathrm{S}\right)$, and $\mathrm{H} 2$ has been reported from Coquimbo $\left(30^{\circ} \mathrm{S}\right)$ (GenBank access number KP059067.1 and KP0599069.1, respectively, Yang et al. 2015).

In this study, haplotype $\mathrm{H} 2$ was detected in all three sampled localities, whereas H1 was found only at Punta Lavapié (Table 1). Interestingly, the two haplotypes reported by Yang et al. (2015) for the Biobío Region (from Cocholgüe and Lebu) were not found in this study despite our samples from nearby localities. On the other hand, both COI haplotypes were obtained from thalli of both forms (Table 1), indicating that morphological, but no genetic, differences exist between them. Furthermore, the divergence between these two haplotypes was only $0.5 \%$ (4 bp), whereas interspecific divergence between $C$. chamissoi and its sister species $C$. teede $i$ is between 2.7-3.8\% (Yang et al. 2015). Thus, even if the haplotypes had been previously related to the forms (one haplotype $=$ one form), variability between them is lower than the divergence threshold generally considered to discriminate among
Table 1. Summary of the COI sequences of thalli of Chondracanthus chamissoi f. lessonii and f. chauvinii from three localities in southern Chile. The frequency of the $\mathrm{H} 1$ and $\mathrm{H} 2$ haplotypes is indicated for each locality and form.

\begin{tabular}{llccc}
\hline Locality & \multicolumn{1}{c}{ Form } & $\begin{array}{c}\mathrm{N}^{\circ} \text { of COI } \\
\text { sequences }\end{array}$ & $\begin{array}{c}\mathrm{H} 1 \\
(\%)\end{array}$ & $\begin{array}{c}\mathrm{H} 2 \\
(\%)\end{array}$ \\
\hline Ramuntcho & f. lessonii & 8 & 0 & 100 \\
Ramuntcho & f. chauvinii & 8 & 0 & 100 \\
Cocholgüe & f. lessonii & 8 & 0 & 100 \\
Cocholgüe & f. chauvinii & 9 & 0 & 100 \\
Punta Lavapié & f. lessonii & 10 & 90 & 10 \\
Punta Lavapié & f. chauvinii & 11 & 91 & 9 \\
\hline
\end{tabular}

Gigartinales species $(<1 \%$ for intraspecific divergence, $>1.5 \%$ for interspecific divergence, with observed values commonly higher than $9 \%$ in the Gigartinales; Le Gall \& Saunders 2010).

The genetic data obtained in this and previous studies are limited in quantity and geographical distribution. Even so, they suggest a low genetic diversity in C. chamissoi, with haplotypes shared between distant localities in the southeast Pacific (Tarapacá-Biobío: $2359 \mathrm{~km}$ of coastline) and low divergence between populations in Chile and Asia (Yang et al. 2015). A phylogeographic study is necessary to reveal the dispersion mechanisms of this species and, in particular, better understand vegetative reproduction's role in its propagation.

It has been shown that $C$. chamissoi has a great capacity for vegetative reproduction by secondary attachment of fragments (Macchiavello et al. 2003, Sáez et al. 2008, Rodríguez \& Otaíza 2018). However, the relative frequency with which this type of reproduction occurs compared to the production of new individuals from spores is unknown. Future research should determine whether vegetative reproduction is common in C. chamissoi, as it has been reported for $C$. pectinatus and C. squarrulosus (Pacheco-Ruiz \& Zertuche-González 1999, 2005). As vegetative reproduction produces genetically identical new individuals, if this type of reproduction were common, then many thalli could be part of widely distributed clones, which could explain the low intraspecific variability found in C. chamissoi (Table 1; Yang et al. 2015).

In sum, differences between phases or sexes (Rodríguez \& Otaíza 2020) cannot explain the occurrence of the two forms of $C$. chamissoi. Also, phenotypic differences resulting from exposure to different environmental conditions cannot explain the two forms. At each site, thalli of both forms were collected in the same patches. On the other hand, our results in this study indicate no evidence that the two 
forms correspond to phylogenetic species, and genetic differences at the intraspecific level were not found. Rodríguez \& Otaíza (2020) propose that the origin of the two forms may be related to the differentiation of the tissues at the tips of the axes associated with the formation of secondary attachment discs. Regrowth after wound healing can produce different morphology types in the same thallus, as has been shown for Solieria filiformis (Perrone \& Cecere 1997), so axes with a different morphology may grow from the secondary attachment discs differentiated from the apexes.

Identifying the mechanism that originates morphological variants in this species, and in the Gigartinaceae, in general, is important given their economic and ecological value (Graham \& Wilcox 2000). The primary market for $C$. chamissoi is as food for humans in Peru and Asian countries, with a marked preference for $\mathrm{f}$. lessonii, considered more palatable (F. Tellier comm. per.). Resolving the mechanisms that result in the modification of thallus morphology could be incorporated into production techniques, positively impacting this algal resource's added value, which is considered one of the red seaweeds with the highest landings in Chile and Peru (PRODUCE 2017, SERNAPESCA 2017).

\section{ACKNOWLEDGMENTS}

This work was partly funded by the CONICYT PFCHA/Magíster Beca Magíster Nacional/2016 22162094, Magíster en Ecología Marina of the Facultad de Ciencias UCSC, Dirección de Postgrado UCSC and the Centro de Investigación en Biodiversidad y Ambientes Sustentables (CIBAS). The authors would also like to acknowledge C. Oyarzún, D. Doherty and D. Esguerra for their help with the fieldwork. The valuable comments from two anonymous reviewers were helpful in improving the original manuscript.

\section{REFERENCES}

Arbaiza, S., Gil-Kodaka, P., Arakaki, N. \& Alveal, K. 2019. Primeros estadios de cultivo a partir de carpósporas de Chondracanthus chamissoi de tres localidades de la costa peruana. Revista de Biología Marina y Oceanografía, 54: 204-213. doi: 10.22370/rbmo.2019.54.2.1901

Altschul, S.F., Gish, W., Miller, W., Myers, E.W. \& Lipman, D.J. 1990. Basic local alignment search tool. Journal of Molecular Biology, 215: 403-410. doi: 10.1016/S0022-2836(05)80360-2

Avila, M., Piel, M.I., Caceres, J.H. \& Alveal, K. 2011. Cultivation of the red alga Chondracanthus chamissoi: sexual reproduction and seedling production in culture under controlled conditions. Journal of Applied Phycology, 23: 529-536. doi: 10.1007/s10811-0109628-1

Boo, G.H., Park, J.K. \& Boo, S.M. 2013. Gelidiophycus (Rhodophyta: Gelidiales): a new genus of marine algae from East Asia. Taxon, 62: 1105-1116. doi: 10.12705/ 626.7

Brodie, J., Guiry, M.D. \& Masuda, M. 1993. Life history, morphology, and crossability of Chondrus ocellatus forma ocellatus and C. ocellatus forma crispoides (Gigartinales, Rhodophyta) from the north-western Pacific. European Journal of Phycology, 28: 183-196. doi: 10.1080/09670269300650281

Bulboa, C. \& Macchiavello, J. 2006. Cultivation of cystocarpic, tetrasporic, and vegetative fronds of Chondracanthus chamissoi (Rhodophyta, Gigartinales) on ropes at two localities in northern Chile. Investigaciones Marinas, Valparaíso, 34: 109-112. doi: 10.4067/S0717-71782006000100010

Bulboa, C., Véliz, K., Sáez, F., Sepúlveda, C., Vega, L. \& Macchiavello, J. 2013. A new method for cultivation of the carragenophyte and edible red seaweed Chondracanthus chamissoi based on secondary attachment disc: development in outdoor tanks. Aquaculture, 410-411: 86-94. doi: 10.1016/j.aquaculture.2013.06.018

Dawson, E., Acleto, C. \& Foldvik, N. 1964. The seaweeds of Peru. Nova Hedwigia, 13: 1-111.

Drew, K.M. 1949. Conchocelis-phase in the life-history of Porphyra umbilicalis (L.) Kütz. Nature, 164: 748-749. doi: 10.1038/164748a0

Edding, M., Tala, F. \& Vásquez, J. 2006. Fotosíntesis, productividad y algas marinas. In: Squeo, F.A. \& Cardemil, L. (Eds.). Fisiología vegetal. Ediciones Universidad de La Serena, La Serena, pp. 1-39.

Faria, A.V.F., Bonomi-Barufi, J. \& Plastino, E.M. 2017. Ecotypes of Gracilaria caudata (Gracilariales, Rhodophyta): physiological and morphological approaches considering life history phases. Journal of Applied Phycology, 29: 707-719. doi: 10.1007/ s10811-016-1018-X

Fonck, E., Martínez, R., Vásquez, J. \& Bulboa, C. 2008. Factors that affect the re-attachment of Chondracanthus chamissoi (Rhodophyta, Gigartinales) thalli. Journal of Applied Phycology, 20: 311. doi: 10.1007/s10811-007-9251-y

Fraser, C.I., Hay, C.H., Spencer, H.G. \& Waters, J.M. 2009. Genetic and morphological analyses of the southern bull kelp Durvillaea antarctica (Phaeophyceae: Durvillaeales) in New Zealand reveal cryptic species. Journal of Phycology, 45: 436-443. doi: 10.1111/j.1529-8817.2009.00658.x 
Gavio, B. \& Fredericq, S. 2002. Grateloupia turuturu (Halymeniaceae, Rhodophyta) is the correct name of the non-native species in the Atlantic known as Grateloupia doryphora. European Journal of Phycology, 37: 349-359. doi: 10.1017/S0967026202003839

Gonzalez, J. \& Meneses, I. 1996. Differences in the early stages of development of gametophytes and tetrasporophytes of Chondracanthus chamissoi (C.Ag.) Kützing from Puerto Aldea, northern Chile. Aquaculture, 143: 91-107. doi: 10.1016/0044-8486(95)01 203-6

Graham, L.E. \& Wilcox, L.W. 2000. Algae. Prentice-Hall, Upper Saddle River, pp. 343-396.

Gurgel, C.F.D. \& Fredericq, S. 2004. Systematics of the Gracilariaceae (Gracilariales, Rhodophyta): a critical assessment based on rbcL sequence analyses. Journal of Phycology, 40: 138-159. doi: 10.1111/j.00223646.2003.02-129. $\mathrm{x}$

Gutierrez, L.M. \& Fernández, C. 1992. Water motion and morphology in Chondrus crispus (Rhodophyta). Journal of Phycology, 28: 156-162. doi: 10.1111/ j.0022-3646.1992.00156.x

Hall, T.A. 1999. BioEdit: a user-friendly biological sequence alignment editor \& analysis program for Windows 95/98/NT. Nucleic Acids Symposium Series, 41: 95-98.

Hoffmann, A. \& Santelices, B. 1997. Flora marina de Chile central. Ediciones de la Universidad Católica de Chile, Santiago.

Howe, M. 1914. The marine algae of Peru. Torrey Botanical Club Memoirs, 15: 99-102.

Hughey, J.R. \& Hommersand, M.H. 2008. Morphological and molecular systematic study of Chondracanthus (Gigartinaceae, Rhodophyta) from Pacific North America. Phycologia, 47: 124-155. doi: 10.2216/0706.1

Kim, J.S., Kim, J.C., Lee, S., Lee, B.H. \& Cho, K.Y. 2006. Biological activity of L-2-azetidinecarboxylic acid, isolated from Polygonatum odoratum var. pluriflorum, against several algae. Aquatic Botany, 85: 1-6. doi: 10.1016/j.aquabot.2006.01.003

Le Gall, L. \& Saunders, G.W. 2010. DNA barcoding is a powerful tool to uncover algal diversity: a case study of the Phyllophoraceae (Gigartinales, Rhodophyta) in the Canadian flora. Journal of Phycology, 46: 374-389. doi: 10.1111/j.1529-8817.2010.00807.x

López, B., Tellier, F., Retamal-Alarcón, J.C., PérezAraneda, K., Fierro, A.O., Macaya, E.C., et al. 2017. Phylogeography of two intertidal seaweeds, Gelidium lingulatum and G. rex (Rhodophyta: Gelidiales), along the southeast Pacific: patterns explained by rafting dispersal? Marine Biology, 164: 188. doi: 10.1007/ s00227-017-3219-5
Macchiavello, J., Bulboa, C. \& Edding, M. 2003. Vegetative propagation and spore recruitment in the carrageenophyte Chondracanthus chamissoi (Rhodophyta, Gigartinales) in northern Chile. Phycological Research, 51: 45-50. doi: 10.1046/j.1440-1835.2003. 00292.x

Otaíza, R.D. \& Fonseca, F.G. 2011. Effect of dissolved calcium on the formation of secondary attachment structures in different types of branches of Chondracanthus chamissoi (Rhodophyta, Gigartinales). Revista de Biología Marina y Oceanografía, 46: 263268. doi: 10.4067/S0718-19572011000200016

Oyarzo, S., Ávila, M., Alvear, P., Remonsellez, J.P., Contreras-Porcia, L. \& Bulboa, C. 2021. Secondary attachment disc of edible seaweed Chondracanthus chamissoi (Rhodophyta, Gigartinales): establishment of permanent thalli stock, Aquaculture, 530: 735954. doi: 10.1016/j.aquaculture.2020.735954

Pacheco-Ruiz, I. \& Zertuche-González, J.A. 1999. Population structure and reproduction of the carrageenophyte Chondracanthus pectinatus in the Gulf of California. In: Kain, J.M., Brown, M.T. \& Lahaye, M. (Eds.). Sixteenth International Seaweed Symposium. Developments in Hydrobiology, Springer, Dordrecht, pp. 159-165.

Pacheco-Ruiz, I., Zertuche-González, J.A. \& EspinozaAvalos, J. 2005. The role of secondary attachment discs in the survival of Chondracanthus squarrulosus (Gigartinales, Rhodophyta). Phycologia, 44: 629-631. doi: 10.2216/0031-8884(2005)44[629:TROSAD]2.0. $\mathrm{CO} ; 2$

Perrone, C. \& Cecere, E. 1997. Regeneration and mechanisms of secondary attachment in Soliera filiformis (Gigartinales, Rhodophyta). Phycologia, 36: 120-127. doi: 10.2216/i0031-8884-36-2-120.1

Ministerio de la Producción del Perú (PRODUCE). 2017. Anuario estadístico pesquero y acuícola. Ministerio de la Producción, Lima. [http://ogeiee.produce.gob.pe/ images/Anuario/ Pesca_2017.pdf]. Reviewed: August 27, 2019.

Ramírez, M.E. \& Santelices, B. 1991. Catálogo de las algas marinas bentónicas de la costa temperada del Pacífico de Sudamérica. Pontificia Universidad Católica de Chile, Santiago.

Rodríguez, C.Y. \& Otaíza, R.D. 2018. Factors affecting morphological transformation and secondary attachment of apexes of Chondracanthus chamissoi (Rhodophyta, Gigartinales). Journal of Applied Phycology, 30: 1157-1166. doi: 10.1007/s10811-0171305-1

Rodríguez, C.Y. \& Otaíza, R.D. 2020. Morphological variability in a red seaweed: confirmation of cooccurring f. lessonii and f. chauvinii in Chondracanthus chamissoi (Rhodophyta, Gigartinales). 
Journal of Phycology, 56: 469-480. doi: 10.1111/jpy. 12955

Sáez, F., Macchiavello, J., Fonck, E. \& Bulboa, C. 2008. The role of the secondary attachment discs in the vegetative propagation of Chondracanthus chamissoi (Gigartinales: Rhodophyta). Aquatic Botany, 89: 6365. doi: 10.1016/j.aquabot.2008.01.004

Santelices, B. 1989. Algas marinas de Chile: distribución ecología, utilización, biodiversidad. Universidad Católica de Chile, Santiago.

Saunders, G.W. 2005. Applying DNA barcoding to red macroalgae: a preliminary appraisal holds promise for future applications. Philosophical Transactions of the Royal Society B, 360: 1879-1888. doi: 10.1098/ rstb.2005.1719

Schneider, C.W. \& Lane, C.E. 2005. Notes on the marine algae of the Bermudas. Additions to the flora, including Chondracanthus saundersii $\mathrm{sp}$. nov. (Rhodophyta, Gigartinaceae) based on $r b c \mathrm{~L}$ sequence analysis. Phycologia, 44: 72-83. doi: 10.2216/00318884(2005)44[72:NOTMAO] 2.0.CO;2

Servicio Nacional de Pesca (SERNAPESCA). 2017. Anuario estadístico de pesca. Ministerio de Economía de Chile, Santiago. [http://www.sernapesca.cl]. Reviewed: August 27, 2019.

Shaughnessy, F.J. 1996. Identification and microgeographic distribution of Mazzaella splendens and Mazzaella linearis (Gigartinaceae, Rhodophyta). Canadian Journal of Botany, 74: 999-1008. doi: $10.1139 / \mathrm{b} 96-124$

Received: 29 November 2019; Accepted: 14 October 2020
Van der Meer, J.P. \& Todd, E.R. 1980. The life history of Palmaria palmata in culture. A new type for the Rhodophyta. Canadian Journal of Botany, 58: 12501256. doi: $10.1139 / \mathrm{b} 80-155$

Vásquez, J.A. \& Vega, J.M.A. 2001. Chondracanthus chamissoi (Rhodophyta, Gigartinales) in northern Chile: ecological aspects for management of wild populations. Journal of Applied Phycology, 13: 267277. doi: 10.1023/A:1011152922832

Yang, M.Y., Geraldino, P.J.L. \& Kim, M.S. 2013. DNA barcode assessment of Gracilaria salicornia (Gracilariaceae, Rhodophyta) from Southeast Asia. Botanical Studies, 54: 27. doi: 10.1186/1999-3110-54-27

Yang, M.Y., Macaya, E.C. \& Kim, M.S. 2015. Molecular evidence for verifying the distribution of Chondracanthus chamissoi and C. teedei (Gigartinaceae, Rhodophyta). Botanica Marina, 58: 103-113. doi: 10.1515/bot-2015-0011

Zapata-Rojas, J.C., Gonzales-Vargas, A.M. \& ZevallosFeria, S.A. 2020. Estudio comparativo para propagación vegetativa de Chondracanthus chamissoi, Yuyo, sobre tres tipos de sustrato en ambiente controlado y su viabilidad en la región Moquegua. Enfoque UTE, 11: 37-47. doi: 10.29019/enfoqueute.v11n 4.642 